\title{
Post-infectious Functional Dyspepsia - A Novel Disease Entity among Functional Gastrointestinal Disorders - Relation to Helicobacter pylori Infection?
}

(Neurogastroenterol Motil 2009;21:832-e56)

Hidekazu Suzuki, M.D., Ph.D.

Division of Gastroenterology and Hepatology, Department of Internal Medicine, Keio University School of Medicine, Tokyo, Japan

\section{Summary}

Kindt et al. ${ }^{1}$ published a report entitled "Intestinal immune activation in presumed post-infectious functional syspepsia" in the August issue of Neurogastroenterology and Motility in 2009. By comparing the signs of inflammation and the degree of hyperplasia of the enterochromaffin cells (EC) in duodenal biopsies obtained from patients with presumed post-infectious functional dyspepsia (PI-FD) and unspecified-onset functional dyspepsia (U-FD), they showed that PI-FD is associated with persistence of focal T-cell aggregates, decrease in $\mathrm{CD} 4{ }^{+}$cells and increased macrophage counts surrounding the crypts, without any significant differences in the numbers of EC or chromogranin A (CA)-positive cells (mast cells). This finding may indicate impaired ability of the immune system in these cases to terminate the inflammatory response after an acute insult.

\section{Comment}

In irritable bowel syndrome (IBS), a post-infectious disease entity was reported in 1962 by Chaudhary and Truelove, who showed that $23 \%$ of IBS patients gave a history of an episode of bacillary or amoebic dysentery. ${ }^{2}$ Ever since, an increasing number of studies have reported on the development of post-infectious IBS.

In relation to $\mathrm{PI}-\mathrm{FD}$, Mearin et $\mathrm{al}^{3}$ reported a significantly increased prevalence of FD up to 1 year after an outbreak of Salmonella gastroenteritis. In PI-FD patients, early satiety, weight loss, nausea, and vomiting are more frequently reported, while gastric sensorimotor function testing revealed a particularly high prevalence of impaired gastric accommodation. ${ }^{4}$ In the study by Kindt et al., ${ }^{1}$ the focal aggregates of $\mathrm{CD} 8{ }^{+} \mathrm{T}$ cells, decrease in $\mathrm{CD}^{+}{ }^{+} \mathrm{T}$ cells and increased macrophage counts surrounding the duodenal crypts persisted for several months after the acute infectious episodes, suggesting delay or impairment of termination of the inflammatory response even after adequate re-

Received: November 17th, 2009 Accepted: November 24th, 2009

(c) This is an Open Access article distributed under the terms of the Creative Commons Attribution Non-Commercial License (http://creativecommons. org/licenses/by-nc/3.0) which permits unrestricted non-commercial use, distribution, and reproduction in any medium, provided the original work is properly cited.

*Correspondence: Hidekazu Suzuki, M.D., Ph.D.

Department of Internal Medicine, Keio University School of Medicine, 35 Shinanomachi, Shinjuku-ku, Tokyo 160-8582, Japan

Tel: +81-3-5363-3914, Fax: +81-3-5363-3967, E-mail: hsuzuki@sc.itc.keio.ac.jp

Financial support: This study was supported by the Keio Gijuku Academic Development Funds (to H.S.).

Conflicts of interest: None. 
moval of the infecting pathogen.

Why did Kindt et al. choose duodenal mucosa over gastric biopsies for the histopathological evaluation in the FD patients? As is well known, FD symptoms are mainly attributable to disturbed gastric function. However, the approach of studying inflammation in the duodenum has been used previously ${ }^{5}$ and in fact, was reported to be more successful for detecting the changes in $\mathrm{FD}$ as compared to gastric biopsies. ${ }^{6}$ According to the report by Lee et al., ${ }^{7}$ since duodenal acidification induces proximal gastric relaxation, increases the sensitivity to gastric distension, and inhibits gastric accommodation to a meal, duodenal mucosa is also an important sensory portion for the pathogenesis of FD. Furthermore, when histological inflammation is assessed by gastric biopsy, we have to bear in mind the possible co-existence of Helicobacter pylori (H. pylori) infection of the stomach. Even though the Rome III classification does not require ruling out of H. pylori infection for diagnosing $\mathrm{FD},{ }^{8,9}$ the $H$. pylori-colonized gastric mucosa exhibits significant levels of inflammatory cell infiltration with $\mathrm{CD} 8^{+}-, \mathrm{CD} 4^{+}-\mathrm{T}$ cells and macrophages. ${ }^{10-13}$ Even after the eradication of $H$. pylori, many mononuclear cells as $\mathrm{T}$ cells or macrophages persist in the mucosa. Such inflammatory changes present before and even after $H$. pylori eradication could play a significant role in the pathophysiology of this type of dyspepsia. Taken together, functional dyspepsia with a present or even past history of $H$. pylori infection should be considered as a different disease entity from FD, such as $H$. pylori-infectious FD or post- $H$. pylori-infectious FD.

In conclusion, the concept of PI-FD is potentially valid and the causal relationship between remnant inflammatory features and the gastroduodenal motor or sensory machinery should be further investigated. However, the major microorganism infecting the stomach, H. pylori, should not be overlooked when considering the pathophysiology of FD, especially in Asia.

\section{References}

1. Kindt S, Tertychnyy A, de Hertogh G, Geboes K, Tack J. Intestinal immune activation in presumed post-infectious functional dyspepsia. Neurogastroenterol Motil 2009;21:832-e56.

2. Chaudhary NA, Truelove SC. The irritable colon syndrome. A study of the clinical features, predisposing causes, and prognosis in 130 cases. Q J Med 1962;31:307-322.

3. Mearin F, Pérez-Oliveras M, Perello A, et al. Dyspepsia and irritable bowel syndrome after a Salmonella gastroenteritis outbreak: one-year follow-up cohort study. Gastroenterology 2005;129:98-104.

4. Tack J, Demedts I, Dehondt G, et al. Clinical and pathophysiological characteristics of acute-onset functional dyspepsia. Gastroenterology 2002;122:1738-1747.

5. Collins JS, Hamilton PW, Watt PC, Sloan JM, Love AH. Quantitative histological study of mucosal inflammatory cell densities in endoscopic duodenal biopsy specimens from dyspeptic patients using computer linked image analysis. Gut 1990;31:858-861.

6. Collins JS, Hamilton PW, Watt PC, Sloan JM, Love AH. Superficial gastritis and Campylobacter pylori in dyspeptic patients--a quantitative study using computer-linked image analysis. J Pathol 1989;158:303-310.

7. Lee KJ, Vos R, Janssens J, Tack J. Influence of duodenal acidification on the sensorimotor function of the proximal stomach in humans. Am J Physiol Gastrointest Liver Physiol 2004;286:G278G284.

8. Tack J, Talley NJ, Camilleri M, et al. Functional gastroduodenal disorders. Gastroenterology 2006;130:1466-1479.

9. Suzuki H, Nishizawa T, Hibi T. Therapeutic strategies for functional dyspepsia and the introduction of the Rome III classification. J Gastroenterol 2006;41:513-523.

10. Suzuki H, Masaoka T, Miyazawa M, Suzuki M, Miura S, Ishii H. Gastric mucosal response to Helicobacter pylori. Keio J Med 2002;51(suppl 2):40-44.

11. Suzuki H, Hibi T, Marshall BJ. Helicobacter pylori: present status and future prospects in Japan. J Gastroenterol 2007;42:1-15.

12. Suzuki H, Iwasaki E, Hibi T. Helicobacter pylori and gastric cancer. Gastric Cancer 2009;12:79-87.

13. Suzuki H, Suzuki M, Imaeda H, Hibi T. Helicobacter pylori and microcirculation. Microcirculation 2009;16:547-558 